\title{
Effect of milk sampling techniques on milk composition, bacterial contamination, viability and functions of resident cells in milk
}

\author{
Frédéric Vangroenweghe, Hilde Dosogne, Jalil MehrZad, \\ Christian BURVENICH*
}

\begin{abstract}
Ghent University, Faculty of Veterinary Medicine, Department of Physiology, Biochemistry and Biometrics, Salisburylaan 133, 9820 Merelbeke, Belgium
\end{abstract}

(Received 4 September 2000; accepted 1 June 2001)

\begin{abstract}
Three different milk sampling techniques were evaluated during milk sampling: a direct aseptic collection from the udder through a sterile cannula was used as the reference technique, compared with either a manual or a mechanical sampling method. In this study 30 high-yielding HolsteinFriesian dairy cows at different stages of lactation and free of udder infection were used. For each milk sample, the influence of milk sampling techniques was determined for the following parameters: somatic cell count, milk composition, bacterial contamination, viability, in vitro phagocytosis and overall killing of Staphylococcus aureus Newbould 305, and cellular chemiluminescence. Because milk sampling occurred throughout lactation, the differences between early, mid- and late lactation were estimated. It was concluded that bacterial contamination was not significantly different in manual milking samples and the reference technique; bacterial contamination was, however, significantly $(P<0.001)$ higher in machine milking samples than in the reference technique. Among the different sampling techniques, no significant effects on SCC, milk composition, viability and functions of the cells isolated from milk were observed. It was found that viability, intracellular killing and cellular chemiluminescence of milk PMN were significantly lower $(P<0.05)$ in early lactation compared to mid-lactation. Phagocytosis was significantly $(P<0.05)$ higher in early lactation compared to mid- and late lactation, and no significant differences were observed between mid- and late lactation. From this study, it can be concluded that despite a higher bacterial contamination obtained with the mechanical sampling method, the 3 milk sampling techniques described in this study can be used for the evaluation of milk cell functions.
\end{abstract}

dairy cow / milk sampling technique / stage of lactation / milk composition / milk neutrophil functions

* Correspondence and reprints

Tel.: (32) 9 2647321; fax: (32) 9 2647499; e-mail: Christian.Burvenich@rug.ac.be 
Résumé - Effet de techniques de prélèvement de lait sur la composition du lait, la contamination bactérienne, la viabilité et les fonctions des cellules résidentes du lait. Trois différentes techniques de prélèvement de lait ont été évaluées. Un prélèvement aseptique direct du pis à l'aide d'une canule stérile, considéré comme technique de référence, a été comparé à une méthode de prélèvement manuel d'une part et une méthode de prélèvement à la machine d'autre part. Dans l'étude 30 vaches Holstein-Friesian à trois stades différents de lactation et sans infection intramammaire ont été utilisées. Dans chaque échantillon de lait, l'influence des techniques de prélèvement a été évaluée à l'aide des paramètres suivants: le taux cellulaire du lait, la composition du lait, la contamination bactérienne, la viabilité des cellules, la phagocytose in vitro et la destruction intracellulaire de Staphylococcus aureus Newbould 305, et la chimioluminescence cellulaire. Comme le prélèvement de lait a été réalisé pendant toute la durée de lactation, des différences entre les périodes de lactation ont pu être déterminées. Cette étude mène aux conclusions suivantes: la contamination bactérienne n'était pas significativement différente entre la méthode manuelle et la technique de référence mais elle était significativement $(P<0.001)$ plus élevée lors du prélèvement à la machine que lors du prélèvement à l'aide d'une canule ; néanmoins, il n'y a pas eu de différences sur le taux cellulaire du lait, la composition du lait, la viabilité et les fonctions des cellules isolées du lait entre les techniques de prélèvement. Pendant la durée de lactation, la viabilité, la destruction intracellulaire et la chimioluminescence cellulaire des PMN isolées du lait étaient significativement $(P<0.05)$ plus basses en début de lactation qu'en milieu de lactation, la phagocytose était significativement $(P<0.05)$ plus élévée en début de lactation qu'en milieu de lactation. Il n'y a pas eu de différence significative de ces paramètres en milieu et en fin de lactation. Les trois techniques de prélèvement décrites dans cette étude peuvent être utilisées pour évaluer les fonctions cellullaires du lait, même si la technique de prélèvement à la machine a provoqué une contamination bactérienne plus élevée.

vache laitière / technique de collection de lait / stade de lactation / composition laitière / neutrophiles isolés du lait

\section{INTRODUCTION}

Mastitis can be defined as an increase in somatic cell count (SCC) above a certain "physiological" threshold. In the past, bulk tank SCC was determined to assess the level of infection in a herd. However, determination of milk SCC from individual cows or even individual quarters is far more relevant. Until now, only the concentration of somatic cells in milk received attention. However, recent advances in the immunology and physiology of the bovine mammary gland have provided tools for studying subpopulations of milk somatic cells and their function.

Bacterial contamination during sampling could influence various cell functions and may interfere with the interpretation of physiological effects on cell function. Bacteria or yeast have been used in assays of phagocytosis, intracellular killing or oxidative burst of stimulated cells [9, 17-19, 22, 23]. Paape and Pearson [17] studied the influence of the isolation procedure of polymorphonuclear neutrophil leukocytes (PMN) in milk on the variation of phagocytosis. They reported that the variation in the milk PMN isolation technique accounted for only $1.5 \%$ of the total variation. The variability between duplicate determinations was $4.4 \%$ of the total variation.

The purpose of the present study was to determine the effect of milk sampling techniques on bacterial contamination, milk composition, total and differential SCC, as well as on the viability and different milk PMN functions. The differences in these parameters among the different stages of lactation were also studied.

\section{MATERIALS AND METHODS}

\subsection{Experimental animals}

Thirty high yielding Holstein-Friesian cows (milk production: $28.5 \pm 1.0 \mathrm{~L} / \mathrm{d}$ ) from 
the Ghent University herd (Biocentrum Agri-Vet, Melle, Belgium) were selected on a basis of the absence of bacteria in two consecutive milk samples and SCC below $200000 / \mathrm{mL}$ per individual quarter. The animals were in their first to fifth lactation and at three different stages of lactation. Early, mid- and late lactating cows averaged $9 \pm 3$ $(n=10), 127 \pm 10(n=10)$ and $271 \pm 12$ $(n=10)$ days of lactation, respectively.

\subsection{Milk sampling techniques}

Three different milk sampling techniques (SPL) were compared: 1) a sterile teat cannula infusion apparatus (STER-SPL), 2) manual hand milking (MAN-SPL) and 3) quarter machine milking (CONT-SPL). Because of practical restrictions, the experiment was divided into 2 separate trials. In trial 1, STER-SPL was compared with MAN-SPL ( $n=15$ cows). In trial 2, STERSPL was compared with CONT-SPL $(n=15$ cows).

In all three sampling techniques, the teat ends were thoroughly disinfected (ethanol 70\%-chlorhexidin) before sample collection. The same quarter was used to perform the different sampling techniques. For MAN-SPL, a volume of $1000 \mathrm{~mL}$ was milked into a sterile pyrex container (volume $1500 \mathrm{~mL}$, diameter opening $50 \mathrm{~mm}$ ) by manual hand milking (15 samples of 15 cows). For STER-SPL a sterile and pyrogen-free cannula was inserted into the teat canal, which was then connected to the free end of an infusion set attached to a $2000 \mathrm{~mL}$ sterile collection bag (Uripac ${ }^{\circledR}$, Vycon, Belgium) (Fig. 1) (30 samples of 30 cows). For CONT-SPL the same fraction of milk was

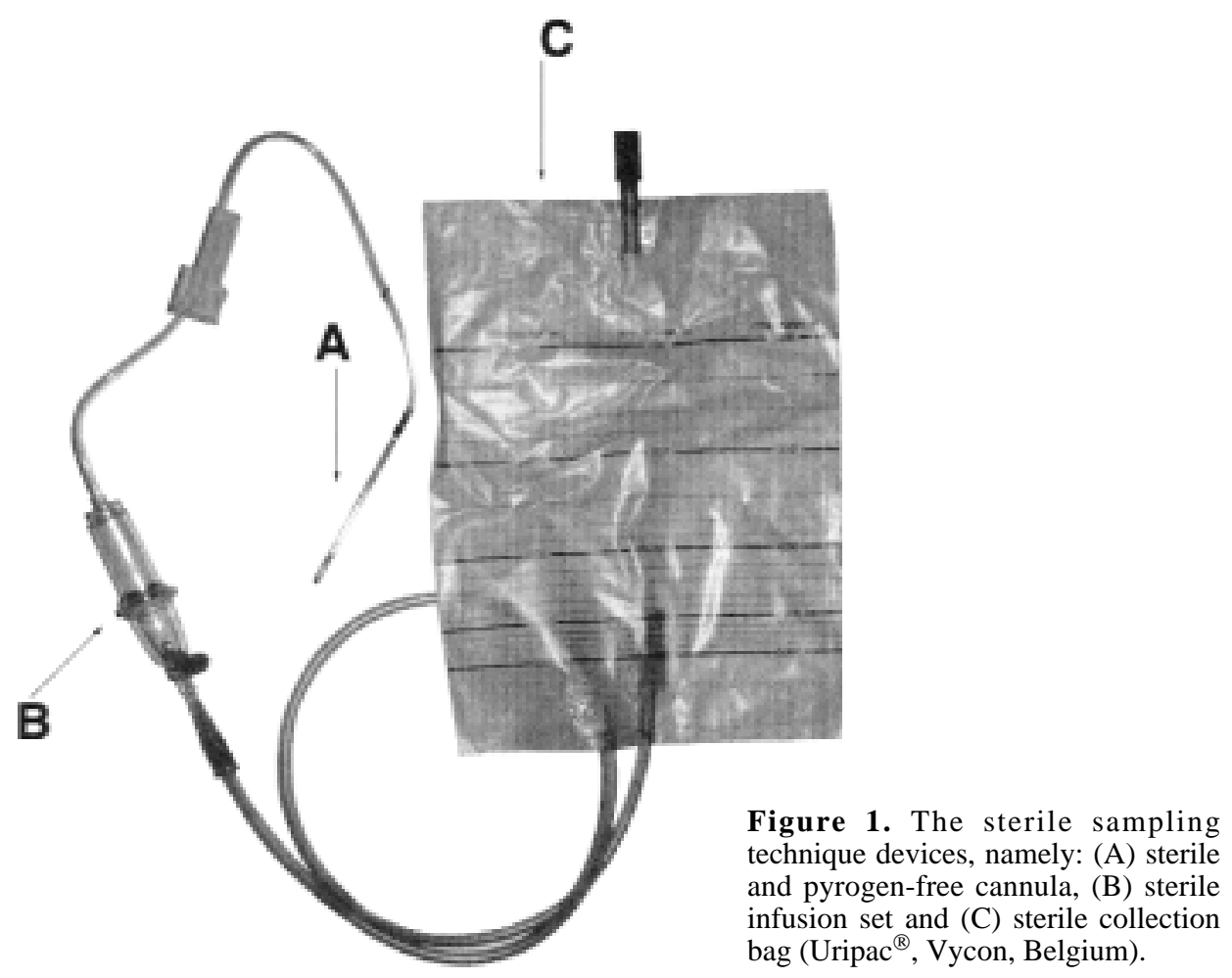


collected using a quarter milking machine (15 samples of 15 cows).

\subsection{Transport of milk samples}

Milk samples were stored in a coolbox with active cooling immediately after sampling. The time interval between sampling and the arrival at the laboratory varied around $46 \pm 5 \mathrm{~min}$. The temperature inside the coolbox on arrival at the laboratory was $17.9 \pm 1.7^{\circ} \mathrm{C}$.

\subsection{Bacterial contamination}

For bacteriological examination $10 \mu \mathrm{L}$ was plated onto a Columbia sheep blood agar (SBA) (Biokar Diagnostics, Beauvais, France) plate with a Transferpette ${ }^{\circledR}$ (Brand $\mathrm{GmbH}$, Wertheim, Germany) and smeared out over the plate with a sterile plastic loop. Each sample was plated out in duplicate and incubated for $24 \mathrm{~h}$ at $37^{\circ} \mathrm{C}$. Colony-forming units (CFU) were counted using the plate counting method.

\subsection{Somatic cell count and milk composition}

The somatic cell count was determined with a fluoro-opto electronic method (Fossomatic 400 cell counter, Foss Electronic, Hillerod, Denmark). Milk fat, protein and lactose concentration were determined by mid-infrared spectrophotometry (Foss Electronic). Glucose concentration was determined using a UV-method (D-Glucose, Roche Diagnostics, Brussels, Belgium).

\subsection{Isolation of milk cells}

The isolation of milk cells was performed as described by Paape et al. [16] with some modifications. Phosphate buffered saline solution $(25 \mathrm{~L})$ was prepared as follows: $5 \mathrm{~L}$ of stock solution $\left(5.5842 \mathrm{~g} \mathrm{KH}_{2} \mathrm{PO}_{4}\right.$, $37.2438 \mathrm{~g} \mathrm{Na}_{2} \mathrm{HPO}_{4}, 40.9 \mathrm{~g} \mathrm{NaCl}$, distilled $\mathrm{H}_{2} \mathrm{O} ; \mathrm{pH}$ adjusted to 7.5 ) was diluted to $25 \mathrm{~L}$ with distilled $\mathrm{H}_{2} \mathrm{O}$ and $180 \mathrm{~g} \mathrm{NaCl}$ were added. The PBS solution was sterilised through filtration with a cellulose acetate filter (pore size $0.2 \mu \mathrm{m}$; Whatman, Maidstone, UK). Milk, diluted 2/1 with sterile PBS, was centrifuged $(1000 \times g, 15 \mathrm{~min}$, $4{ }^{\circ} \mathrm{C}$ ) and the cream was removed after the first centrifugation. The cell pellet was washed twice in PBS and the cells were finally resuspended in Hank balanced salt solution (HBSS, GIBCO Life Technologies, Paisley, UK) containing $\mathrm{Ca}^{2+}$ and $\mathrm{Mg}^{2+}$ supplemented with $0.1 \%$ bovine serum albumin (BSA, low endotoxin; Sigma Chemicals, St. Louis, MO, USA) and $25 \mathrm{mM}$ HEPES buffer (Sigma).

During isolation, the cells were maintained on melting ice $\left(1^{\circ} \mathrm{C}\right)$. Isolated cells were counted using an electronic particle counter (Coulter Counter Z2, Coulter Electronics Ltd., Luton, England) and viability was determined. The milk cells were resuspended to a concentration of $5 \times 10^{6}$ viable milk cells/mL with HBSS containing $\mathrm{Ca}^{2+}$ and $\mathrm{Mg}^{2+}$ supplemented with $0.1 \% \mathrm{BSA}$ and $25 \mathrm{mM}$ HEPES buffer. The isolation ended $181 \pm 16 \mathrm{~min}$ after sampling.

\subsection{Viability and differential counts of isolated milk cells}

Viability was assessed within $189 \pm 17 \mathrm{~min}$ after sampling. The viability of milk cells was quantified by flow cytometry (FACScan, Becton Dickinson Immunocytometry Systems, San José, CA, USA) using propidium iodide exclusion (PI, $50 \mu \mathrm{g} / \mathrm{mL}$ PBS, Sigma Chemicals, St. Louis, MO, USA). Determination of viability was carried out in triplicate. The mean value of the 3 determinations was used in further calculations.

Differential counts of isolated milk cells were carried out as described by Dulin et al. [8]. Two hundred cells were counted on 
each of the 60 smears and the percentages of PMN, macrophages and lymphocytes were determined. These data were used to correct intracellular killing and CL for the percentage of PMN in the isolated milk cells.

\subsection{Neutrophil function tests}

Phagocytosis and overall killing of S. aureus Newbould 305 was evaluated in a bacteriological assay according to Barta [2] and Barrio et al. [1] with few modifications for milk. The assay was run in duplicate in Eppendorf ${ }^{\circledR}$ tubes (Netheler-Hinz GmbH, Hamburg, Germany) in a final volume of $1 \mathrm{~mL}$ with the following composition: $500 \mu \mathrm{L}$ isolated cells $\left(5 \times 10^{6}\right.$ viable cells $/ \mathrm{mL}), 100 \mu \mathrm{L} S$. aureus Newbould 305 suspension $\left(1 \times 10^{8} \mathrm{CFU} / \mathrm{mL}\right)$ and $400 \mu \mathrm{L}$ pooled bovine serum diluted to a final concentration (v/v) of 5\% (complement-inactivated, $56{ }^{\circ} \mathrm{C}, 30 \mathrm{~min}$ ). Control samples contained bacteria, HBSS and serum without PMN. The bacteria to PMN ratio was between 4:1 and 5:1.

The results from the bacteriological assay were expressed as the percentages of killed (\% killing) and phagocytosed (\% phagocytosis) bacteria and were corrected for the percentage of PMN and macrophages in the samples of isolated milk cells as described by Dosogne et al. [7]. The bacteriological assay was started within $230 \pm 29$ min after sampling.

Luminol-enhanced PMA (phorbol 12myristate 13-acetate) stimulated cellular chemiluminescence (CL) of milk PMN was quantified on isolated milk cells as described by Mehrzad et al. [13]. Non-stimulated CL was compared with PMA-stimulated CL. The area under the curve (AUC) was calculated for the registrated impulse rate over a 30 min period. The CL response was corrected for 1000 viable PMN. Cellular CL measurement was started within $218 \pm 29 \mathrm{~min}$ after sampling.

\subsection{Statistical analysis}

Differences between sampling techniques for SCC, milk composition, bacterial contamination, viability, differential cell counts, phagocytosis, overall killing, PMA-stimulated and non-stimulated CL and differences among stages of lactation were evaluated by least squares ANOVA with Bonferroni correction (Statistix ${ }^{\circledR}$, Analytical Software, Tallahassee, FL, USA). The model includes the sampling procedure, stage of lactation, and second-order interactions between these main effects. Correlation coefficients were determined using the Pearson correlation. Significant differences were determined at $P<0.05^{*}, P<0.01^{* *}$, and $P<0.001^{* * *}$.

\section{RESULTS}

\subsection{SCC, milk composition}

In trial 1, no significant difference in SCC, fat, protein, lactose and glucose content was found between STER-SPL and MAN-SPL milk sampling (Tab. I). In both groups, no significant differences in SCC, fat, protein, lactose and glucose content were observed between the different stages of lactation (Tab. I).

In trial 2, no significant difference in SCC, protein, fat, lactose and glucose content was found between STER-SPL and CONT-SPL milk sampling (Tab. II). Protein content in both groups was significantly $(P<0.05)$ lower during mid-lactation compared to late lactation. No significant difference in protein content was observed between early and late lactation, nor between mid- and late lactation. For SCC, fat, lactose and glucose concentration, no significant differences were observed throughout lactation (Tab. II).

\subsection{Bacterial contamination}

In trial 1 , the bacterial contamination was not significantly different between 
Table I. SCC and milk composition of STER-SPL and MAN-SPL milk samples at different stages of lactation (trial 1). Data are presented as means \pm s.e.m.

\begin{tabular}{|c|c|c|c|}
\hline & \multicolumn{3}{|c|}{ Stage of lactation } \\
\hline & EARLY & MID & LATE \\
\hline \multicolumn{4}{|c|}{ SCC $(\log$ cells/mL $)$} \\
\hline STER-SPL & $4.4 \pm 4.1$ & $4.9 \pm 4.3$ & $5.1 \pm 4.8$ \\
\hline$M A N-S P L$ & $4.5 \pm 3.9$ & $4.7 \pm 4.2$ & $5.1 \pm 4.8$ \\
\hline \multicolumn{4}{|l|}{ FAT $(\mathrm{g} / \mathrm{L})$} \\
\hline STER-SPL & $24.2 \pm 5.2$ & $18.7 \pm 2.8$ & $27.6 \pm 12.3$ \\
\hline$M A N-S P L$ & $22.3 \pm 4.6$ & $17.0 \pm 4.3$ & $19.6 \pm 2.7$ \\
\hline \multicolumn{4}{|c|}{ PROTEIN (g/L) } \\
\hline STER-SPL & $39.5 \pm 2.6$ & $35.3 \pm 0.7$ & $38.1 \pm 2.9$ \\
\hline$M A N-S P L$ & $40.1 \pm 2.8$ & $33.2 \pm 3.0$ & $42.0 \pm 4.0$ \\
\hline \multicolumn{4}{|c|}{ LACTOSE (g/L) } \\
\hline STER-SPL & $49.3 \pm 1.5$ & $52.0 \pm 0.8$ & $48.0 \pm 2.0$ \\
\hline$M A N-S P L$ & $50.1 \pm 1.6$ & $48.8 \pm 4.4$ & $45.2 \pm 3.0$ \\
\hline \multicolumn{4}{|c|}{ GLUCOSE (mg/L) } \\
\hline STER-SPL & $93.6 \pm 11.2$ & $95.6 \pm 20.8$ & $121.9 \pm 23.0$ \\
\hline$M A N-S P L$ & $102.0 \pm 0.8$ & $140.5 \pm 42.0$ & $126.6 \pm 21.7$ \\
\hline
\end{tabular}

STER-SPL: sterile milk sampling technique through a sterile teat cannula

MAN-SPL: manual milk sampling technique

Table II. SCC and milk composition of STER-SPL and CONT-SPL milk samples at different stages of lactation (trial 2). Data are presented as means \pm s.e.m.

\begin{tabular}{|c|c|c|c|}
\hline & \multicolumn{3}{|c|}{ Stage of lactation } \\
\hline & EARLY & MID & LATE \\
\hline \multicolumn{4}{|c|}{ SCC (log cells/mL) } \\
\hline STER-SPL & $4.4 \pm 4.0$ & $4.5 \pm 4.3$ & $4.9 \pm 4.5$ \\
\hline CONT-SPL & $4.9 \pm 4.7$ & $4.7 \pm 4.2$ & $4.9 \pm 4.4$ \\
\hline \multicolumn{4}{|l|}{ FAT (g/L) } \\
\hline STER-SPL & $25.5 \pm 5.8$ & $19.1 \pm 3.3$ & $33.2 \pm 3.7$ \\
\hline CONT-SPL & $42.8 \pm 7.0$ & $25.4 \pm 6.9$ & $33.4 \pm 4.5$ \\
\hline \multicolumn{4}{|l|}{ PROTEIN (g/L) } \\
\hline STER-SPL & $39.0 \pm 3.7$ & $30.9 \pm 4.1^{\mathrm{a}}$ & $39.5 \pm 1.2^{\mathrm{a}}$ \\
\hline$C O N T-S P L$ & $37.3 \pm 3.6$ & $34.2 \pm 0.7^{\mathrm{a}}$ & $39.1 \pm 1.3^{\mathrm{a}}$ \\
\hline \multicolumn{4}{|c|}{ LACTOSE (g/L) } \\
\hline STER-SPL & $49.3 \pm 2.1$ & $50.6 \pm 0.7$ & $49.7 \pm 1.0$ \\
\hline CONT-SPL & $46.2 \pm 2.7$ & $49.9 \pm 0.8$ & $49.3 \pm 0.8$ \\
\hline \multicolumn{4}{|c|}{ GLUCOSE (mg/L) } \\
\hline STER-SPL & $106.9 \pm 12.9$ & $133.2 \pm 18.5$ & $97.4 \pm 19.9$ \\
\hline$C O N T-S P L$ & $94.0 \pm 9.7$ & $170.4 \pm 4.0$ & $113.0 \pm 16.0$ \\
\hline
\end{tabular}

STER-SPL: sterile milk sampling technique through a sterile teat cannula CONT-SPL: milk sampling technique using a quarter milking device

a Significant difference: mid - late lactation $(P<0.05)$. 
STER-SPL and MAN-SPL milk sampling (Tab. III).

No significant differences in the bacterial contamination were observed among the different stages of lactation for both groups.

In trial 2, the bacterial contamination was significantly $(P<0.001)$ higher in CONTSPL compared to STER-SPL milk sampling (Tab. III). No significant difference in the bacterial contamination was observed between the different stages of lactation for both groups.

\subsection{Viability}

In trial 1, no significant difference in viability was found between STER-SPL and MAN-SPL milk sampling (Fig. 2a). However, in both groups, the viability was significantly lower in early lactation compared to mid- $(P<0.001)$ and late $(P<0.01)$ lactation. No significant difference in viability was observed between mid- and late lactation.

In trial 2, no significant difference in viability was found between STER-SPL and CONT-SPL milk sampling (Fig. 2b). However, in both groups, the viability was significantly $(P<0.01)$ lower in early lacta- tion compared to late lactation. No significant difference in viability was observed between early and mid-lactation, nor between mid- and late lactation.

\subsection{Differentiation of isolated cells}

In trial 1, no significant difference in cell differentiation was found between STERSPL and MAN-SPL (Tab. IV). However, in both groups the percentage of PMN was significantly $(P<0.05)$ lower in early lactation compared to late lactation. No significant difference in the percentage of PMN was observed between early and midlactation, nor between mid- and late lactation. In both groups, the percentage of macrophages was not significantly different between the different stages of lactation. The percentage of lymphocytes in both groups was significantly higher $(P<0.01)$ in early lactation compared to mid- and late lactation. No significant difference in the percentage of lymphocytes was observed between mid- and late lactation.

In trial 2, no significant difference in cell differentiation was found between STERSPL and CONT-SPL (Tab. V). In both groups, however, the percentage of PMN was significantly lower $(P<0.01)$ in

Table III. Bacterial contamination (cfu/mL) from STER-SPL, MAN-SPL and CONT-SPL milk samples at different stages of lactation (trial 1 and 2). Data are presented as means \pm s.e.m.

\begin{tabular}{lccc}
\hline & \multicolumn{3}{c}{ Stage of lactation } \\
\cline { 2 - 4 } & EARLY & MID & LATE \\
\hline TRIAL 1 & 0 & 0 & 0 \\
STER-SPL & $660 \pm 413$ & $1480 \pm 1020$ & $5380 \pm 4325$ \\
MAN-SPL & $0^{\text {a }}$ & $0^{\text {a }}$ & $0^{\text {a }}$ \\
TRIAL 2 & $6620 \pm 2339^{\text {a }}$ & $4790 \pm 1641^{\text {a }}$ & $4100 \pm 1496^{\text {a }}$ \\
STER $-S P L$ & CONT-SPL &
\end{tabular}

STER-SPL: sterile milk sampling technique through a sterile teat cannula MAN-SPL: manual milk sampling technique

CONT-SPL: milk sampling technique using a quarter milking device

${ }^{a}$ Significant difference: STER-SPL $v s$. CONT-SPL $(P<0.001)$. 

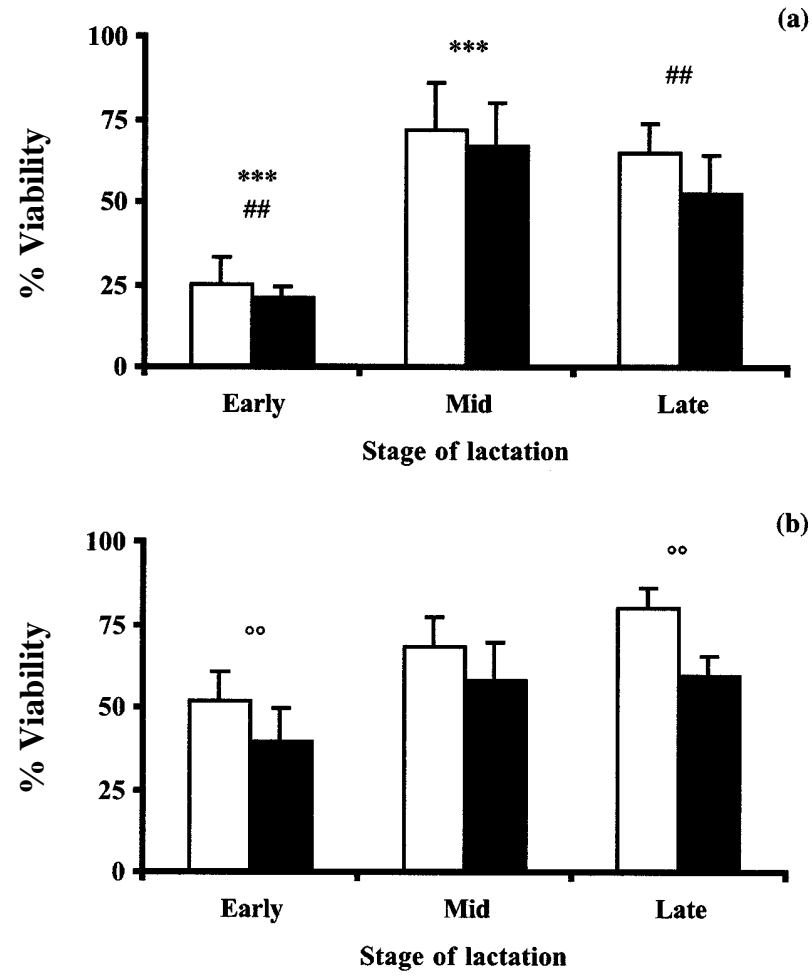

Figure 2. Viability of PMN: (a) trial 1: STER-SPL $\square$ vs. MAN-SPL $\square$ milk samples, and (b) trial 2: STER-SPL $\square v s$. CONT-SPL $\square$ milk samples at different stages of lactation. Data are presented as means \pm s.e.m. Significant differences: $* * *$ early $-\operatorname{mid}(P<0.001)$, \#\# early - late $(P<0.01),{ }^{\circ}$ early - late $(P<0.01)$.

Table IV. Differential SCC as percentages of PMN, macrophages and lymphocytes after isolation of STER-SPL and MAN-SPL milk samples at different stages of lactation (trial 1). Data are presented as means (in \%) \pm s.e.m.

\begin{tabular}{lccc}
\hline & \multicolumn{3}{c}{ Stage of lactation } \\
\cline { 2 - 4 } & EARLY & MID & LATE \\
\hline PMN (\%) & & & \\
STER-SPL & $41.6 \pm 6.2^{\mathrm{a}}$ & $53.6 \pm 9.2$ & $65.4 \pm 1.4^{\mathrm{a}}$ \\
MAN-SPL & $45.6 \pm 1.7^{\mathrm{a}}$ & $58.4 \pm 7.3$ & $57.8 \pm 6.1^{\mathrm{a}}$ \\
Macrophages (\%) & & & \\
STER-SPL & $37.8 \pm 4.9$ & $29.6 \pm 7.3$ & $23.4 \pm 2.2$ \\
MAN-SPL & $30.0 \pm 1.1$ & $34.8 \pm 7.3$ & $30.2 \pm 4.7$ \\
Lymphocytes (\%) & $20.6 \pm 1.6^{\mathrm{bc}}$ & $17.0 \pm 5.0^{\mathrm{b}}$ & $11.2 \pm 2.1^{\mathrm{c}}$ \\
STER-SPL & $24.4 \pm 1.1^{\mathrm{bc}}$ & $6.8 \pm 1.8^{\mathrm{b}}$ & $12.0 \pm 3.3^{\mathrm{c}}$ \\
MAN-SPL & &
\end{tabular}

STER-SPL: sterile milk sampling technique through a sterile teat cannula MAN-SPL: manual milk sampling technique

Significant differences: ${ }^{\mathrm{a}}$ early - late $(P<0.05),{ }^{\mathrm{b}}$ early $-\operatorname{mid}(P<0.01),{ }^{\mathrm{c}}$ early - late $(P<0.01)$. 
Table V. Differential SCC as percentages of PMN, macrophages and lymphocytes after isolation of STER-SPL and CONT-SPL milk samples at different stages of lactation (trial 2). Data are presented as means (in \%) \pm s.e.m.

\begin{tabular}{lccc}
\hline & \multicolumn{3}{c}{ Stage of lactation } \\
\cline { 2 - 4 } & EARLY & MID & LATE \\
\hline PMN (\%) & $52.2 \pm 11.9$ & $45.6 \pm 8.0^{\mathrm{a}}$ & $72.4 \pm 3.6^{\mathrm{a}}$ \\
STER-SPL & $44.8 \pm 10.7$ & $43.2 \pm 4.6^{\mathrm{a}}$ & $68.0 \pm 4.6^{\mathrm{a}}$ \\
CONT-SPL & & & \\
Macrophages (\%) & $23.2 \pm 4.6$ & $20.0 \pm 2.3$ & $15.8 \pm 2.3$ \\
STER-SPL & $27.6 \pm 3.9$ & $23.2 \pm 2.4$ & $20.0 \pm 3.7$ \\
CONT-SPL & & & \\
Lymphocytes $(\%)$ & $11.8 \pm 1.5$ & $34.4 \pm 6.3^{\mathrm{b}}$ & $24.6 \pm 9.1^{\mathrm{b}}$ \\
STER-SPL & $27.6 \pm 9.2$ & $35.6 \pm 7.8^{\mathrm{b}}$ & $12.0 \pm 2.3^{\mathrm{b}}$ \\
CONT-SPL & &
\end{tabular}

STER-SPL: sterile milk sampling technique through a sterile teat cannula

CONT-SPL: milk sampling technique using a quarter milking device

Significant differences: ${ }^{\mathrm{a}}$ mid - late $(P<0.01)$, ${ }^{\mathrm{b}}$ mid - late $(P<0.01)$.

mid-lactation compared to late lactation. No significant difference in the percentage of PMN was observed between early and late lactation, nor between mid- and late lactation. In both groups, the percentage of macrophages was not significantly different between the different stages of lactation. The percentage of lymphocytes in both groups was significantly $(P<0.01)$ higher in mid-lactation compared to late lactation. No significant difference was observed between early and late lactation, nor between early and mid-lactation.

A significant negative correlation ( $r=-0.62 ; P<0.001)$ was observed between the percentage of macrophages and the percentage of PMN and between the percentage of lymphocytes and the percentage of PMN $(r=-0.79 ; P<0.001)$. A significant positive correlation $(r=0.32 ; P<0.05)$ was observed between SCC and the percentage of $\mathrm{PMN}$ and a significant negative correlation $(r=-0.42 ; P<0.001)$ was found between the percentage of lymphocytes and SCC. No other significant correlations were observed between the different parameters.

\subsection{Phagocytosis and overall killing of $S$. aureus}

In trial 1, no significant difference in phagocytosis and overall killing of $S$. aureus was observed between STER-SPL and MAN-SPL milk sampling (Figs. 3a and 4a). However, in both groups the phagocytosis of $S$. aureus was significantly $(P<0.05)$ higher in early lactation compared to mid-lactation. No significant difference in phagocytosis was observed between early and late lactation, nor between mid- and late lactation. The overall killing of $S$. aureus in both groups was significantly lower in early lactation compared to mid- $(P<0.01)$ lactation. No significant difference in the overall killing of $S$. aureus was observed between early and late lactation nor between midand late lactation.

In trial 2, no significant difference in the phagocytosis and overall killing of $S$. aureus was observed between STER-SPL and CONT-SPL milk sampling (Figs. $3 \mathrm{~b}$ and 4b). Moreover, no significant difference in the phagocytosis and overall killing of $S$. aureus was observed between the different stages of lactation for both groups. 

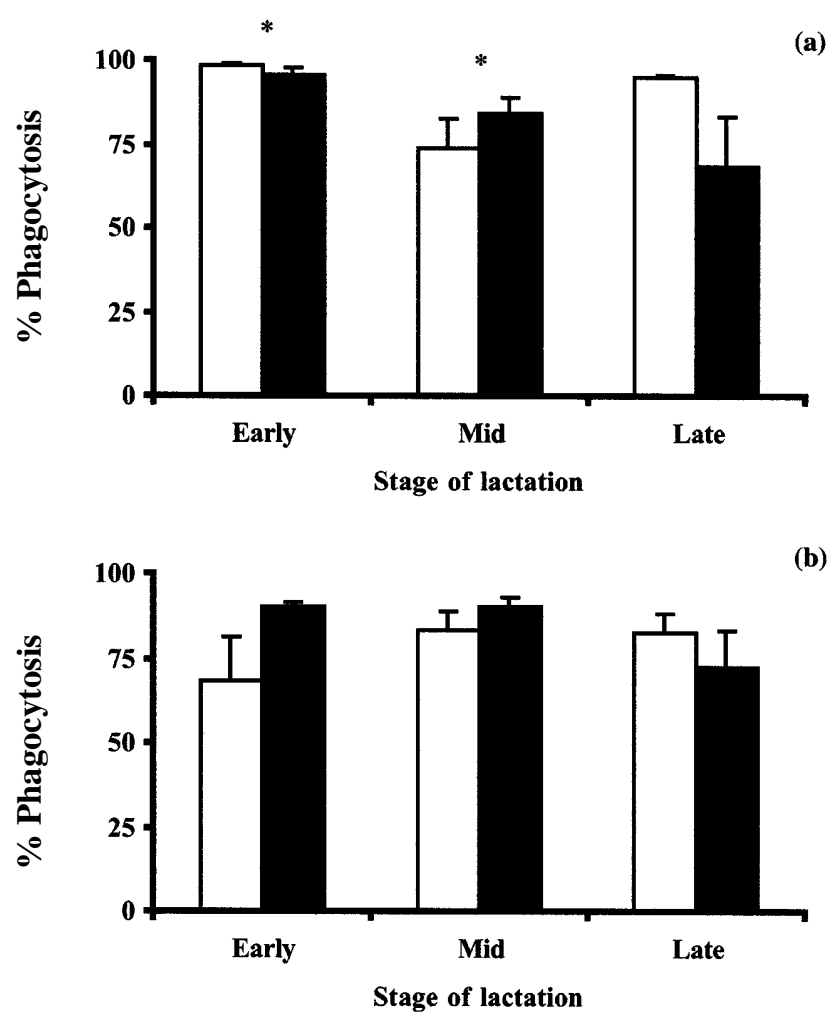

Figure 3. Phagocytosis of $S$. aureus: (a) trial 1: STER-SPL $\square v s$. MAN-SPL $\square$ milk samples, and (b) trial 2: STER-SPL $\square v s$. CONT-SPL $\square$ milk samples at different stages of lactation. Data are expressed as means \pm s.e.m. Significant difference: $*$ early $-\operatorname{mid}(P<0.05)$.

\subsection{PMA-stimulated and non-stimulated chemiluminescence}

In trial 1, no significant difference in PMA-stimulated and non-stimulated CL was observed between STER-SPL and MAN-SPL milk sampling (Figs. 5a and 6a). However, in both groups the PMA-stimulated $C L$ in early lactation was significantly lower compared to mid- $(P<0.001)$ lactation. No significant difference in the PMAstimulated CL was observed between early and late lactation, nor between mid- and late lactation. The non-stimulated CL in both groups was significantly higher in mid-lactation $(P<0.001)$ compared to early and late lactation. No significant difference in the non-stimulated CL was observed between early and late lactation.

In trial 2, no significant difference in PMA-stimulated and non-stimulated CL was observed between STER-SPL and CONT-SPL milk sampling (Figs. 5b and 6b). In early lactation, however, the PMA-stimulated CL was significantly lower compared to mid- $(P<0.010)$ and late $(P<0.05)$ lactation in both groups. No significant difference in PMA-stimulated CL was observed between mid- and late lactation in both groups. The non-stimulated CL in early lactation was significantly lower compared to mid- $(P<0.05)$ lactation in both groups. No significant difference was observed between 

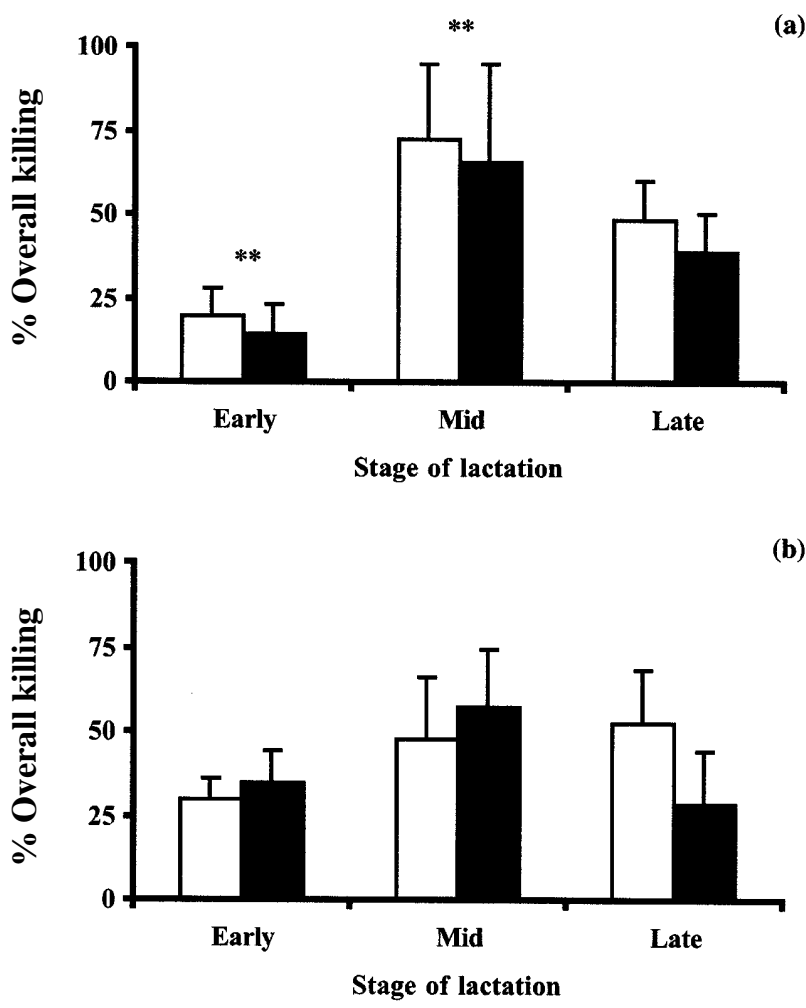

Figure 4. Overall killing of $S$. aureus: (a) trial 1: STER-SPL $\square$ vs. MAN-SPL $\square$ milk samples, and (b) trial 2: STER-SPL $\square v$ s. CONT-SPL $\square$ milk samples at different stages of lactation. Data are expressed as means \pm s.e.m. Significant difference: ** early $-\operatorname{mid}(P<0.01)$.

early and late lactation, nor between midand late lactation in both groups.

A significant positive correlation $(r=0.50 ; P<0.001)$ was found between overall killing and PMA-stimulated CL.

\section{DISCUSSION}

In the present study, the viability and function of milk cells were studied in healthy mammary glands with low SCC. Therefore, normal milk was obtained without stimulation of the mammary gland and all milk samples had low SCC (less than $1.5 \times 10^{5}$ cells $\left./ \mathrm{mL}\right)$. In previous studies,
PMN recruitment into the mammary gland was stimulated by either the insertion of an intramammary device $[16,19]$, or by intramammary infusion of Escherichia coli endotoxin [8].

In the present study, a new sterile milk sampling technique (STER-SPL) was used as a reference technique. This technique allowed milk sampling under absolute sterile conditions without any external contamination. Although manual milk sampling (MAN-SPL) could increase the risk of external contamination, bacterial cell counts by this sampling technique were unexpectedly low. In this milk, no change in viability and different cell functions of isolated milk cells 

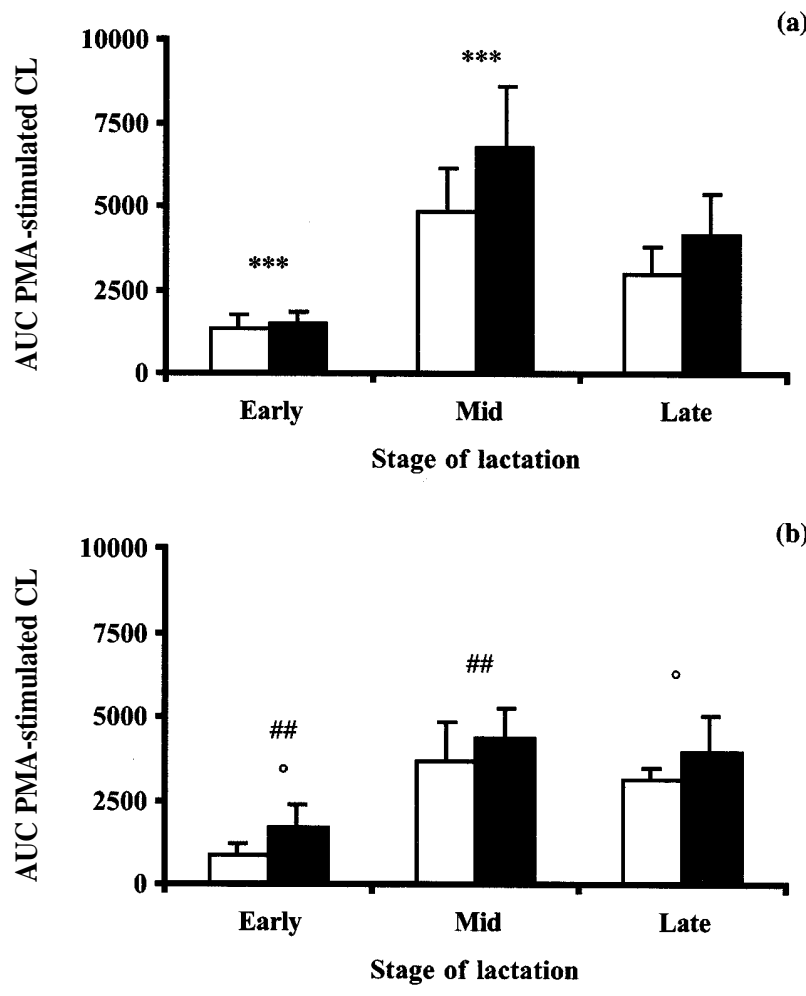

Figure 5. PMA-stimulated chemiluminescence: (a) trial 1: STER-SPL $\square$ vs. MAN-SPL $\square$ milk samples, and (b) trial 2: STER-SPL $\square v$ s. CONT-SPL $\square$ milk samples at different stages of lactation. Data are expressed as means \pm s.e.m. Significant differences: *** early - mid $(P<0.001)$, \#\# early - mid $(P<0.01),{ }^{\circ}$ early - late $(P<0.05)$.

was observed. In contrast, machine milking (CONT-SPL) had a significant higher contamination level as compared to STER-SPL. Despite this bacterial contamination, no significant differences in viability and different cell functions of isolated milk cells were found. It seems that the observed bacterial contamination could not significantly activate these milk cells. However, it is important to mention that the whole study was performed on milk, which was slowly cooled down to $1{ }^{\circ} \mathrm{C}$. Under these conditions, cell functions are inhibited and cells do not react when challenged by these contaminating bacteria. Nevertheless, milk cells did not lose their reaction potential, since they performed CL, intracellular killing and phagocytosis when collected and maintained under the specified conditions. It can be concluded that all three milk sampling techniques are equally appropriate for the study of cellular and non-cellular qualities of bovine milk and resident cells. The reference technique (sterile cannula) is the best for eliminating bacterial contamination.

The lower SCC observed in early lactation cows in our study, compared to midand late lactation cows, is consistent with other longitudinal studies with healthy cows $[12,20]$. Moreover, the slight positive correlation $(r=0.32 ; P<0.05)$ between the 

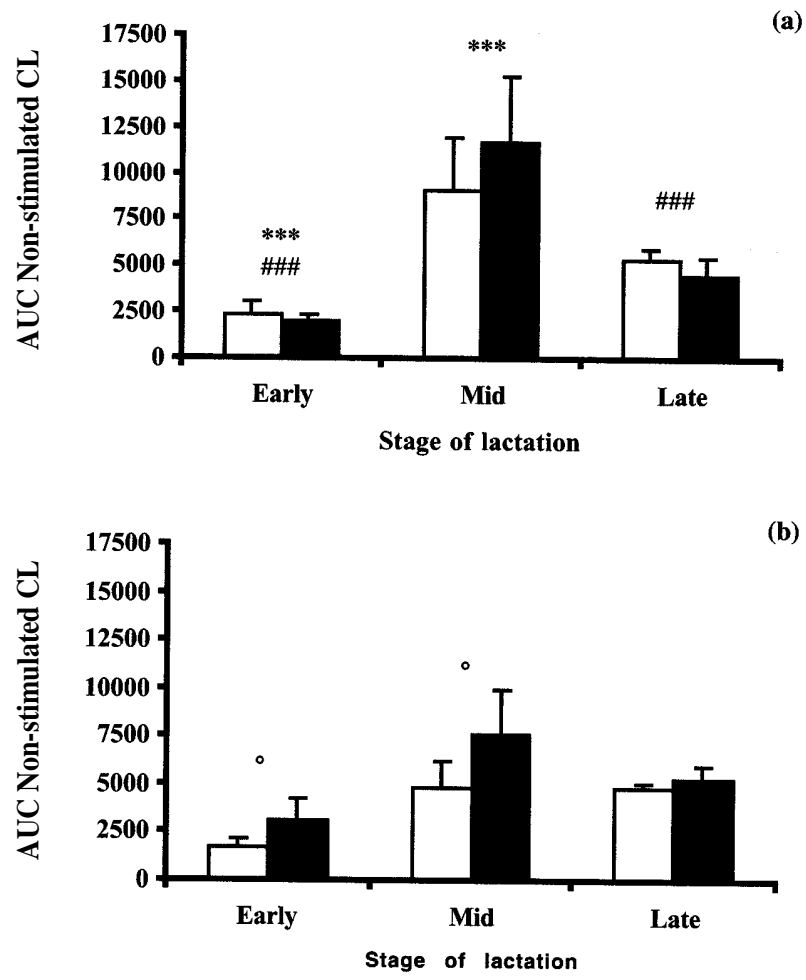

Figure 6. Non-stimulated chemiluminescence: (a) trial 1: STER-SPL $\square v s$. MAN-SPL $\square$ milk samples, and (b) trial 2: STER-SPL $\square v$ s. CONT-SPL $\square$ milk samples at different stages of lactation. Data are expressed as means \pm s.e.m. Significant differences: *** early - mid $(P<0.001)$, \#\#\# early - late $(P<0.001),{ }^{\circ}$ early $-\operatorname{mid}(P<0.05)$.

percentage of PMN and SCC means that the healthy mammary gland with low SCC has a minor PMN influx, whereas a mammary gland with high SCC has a more pronounced PMN influx. The low SCC in early lactation has been associated with a severe outcome of experimentally induced $E$. coli infection of the mammary gland [21, 24], and with a failure of PMN bactericidal efficiency during $S$. aureus mastitis $[4,19]$.

The low viability of milk PMN observed in all stages of lactation, more specifically in early lactation, compared to the high values observed in blood [1, 7, 10], may be explained by a deficient energy level within the cells following the energy-consuming process of diapedesis through the bloodmilk barrier. The relative lack of energy source at the mammary gland level could compromise the viability of these resident milk PMN. Therefore, the glucose concentration in each milk sample was determined. The glucose concentration in milk was only 1/10th of the blood concentration. Naidu and Newbould [15] found that PMN in milk had a decreased intracellular glycogen content compared to blood PMN. Because the cells collected in our study were a mixture of cells that migrated into the gland through a $12 \mathrm{~h}$ period between two consecutive milkings, the oldest cells were already $12 \mathrm{~h}$ in 
this low energy environment. We found that the viability of cells in early lactation was significantly lower compared to mid- and late lactation in both experimental trials. However, the glucose concentration was not significantly different throughout the different stages of lactation. Moreover, no correlation was found between the viability of the milk PMN and the glucose concentration in each sample.

The bactericidal activity of milk PMN against $S$. aureus was the lowest in early lactation, which could be partly explained by a higher number of apoptotic cells within the total cell population of viable cells used in the bacteriological assay. The method used for the determination of viability in milk PMN allowed the differentiation between necrotic PMN on the one hand and living or apoptotic PMN on the other hand. The lower viability observed in early lactation cannot be used to fully explain the observed decrease in overall killing, since the number of viable PMN in each bacteriological assay was approximately the same $\left(5 \times 10^{6}\right.$ viable cells $\left./ \mathrm{mL}\right)$.

Williams et al. [25] found that with an increasing bacteria:neutrophil ratio, the number of phagocytosed bacteria increased proportionately but the intracellular killing was impaired. The observed variation in the ratio (between 4:1 and 5:1) used in this study was not large enough to explain the observed impairment of overall killing during early lactation.

Phagocytosis was found to be higher in early lactation compared to mid- and late lactation and no correlation was found between phagocytosis and overall killing. This is in contrast with other studies [25], where PMN, with a high rate of phagocytosis, more efficiently killed the internalised S. aureus.

The observed decrease in cellular CL in early lactation cows is in accordance with other studies [5, 6, 11, 13, 14]. Moreover, a significant positive correlation $(r=0.50$; $P<0.001)$ was found between overall killing and PMA-stimulated CL [13]. This is in agreement with the results obtained by Williams et al. [25], who demonstrated that intracellular survival but not phagocytosis of $S$. aureus was correlated with reduced CL by bovine PMN. It was demonstrated by Vandeputte-Van Messom et al. [24], that blood PMN from cows with a low reactive oxygen species generating capacity has low circulating glucose levels. Moreover, these cows became severly ill when $E$. coli mastitis was induced experimentally and were termed "severe responders".

When the different cellular functions important to the combat of intramammary infection are put together, it is obvious that dairy cows in early lactation have a higher risk of infection. Firstly, the SCC in early lactation is low and PMN - only about $12 \%$ of the SCC in the healthy gland [3] - are less viable. Secondly, the intracellular mechanism to destroy phagocytosed bacteria is deficient, which could be concluded from the decrease in the overall killing and cellular chemiluminescence.

\section{ACKNOWLEDGEMENTS}

This study was supported by the Belgian Ministry of Small Enterprises and Agriculture (Grant number S/5871) and the Fund for Scientific Research (NFWO/NFRS) (Grant number 31504200).

\section{REFERENCES}

[1] Barrio B., Vangroenweghe F., Dosogne H., Burvenich C., Decreased neutrophil bactericidal activity during phagocytosis of a slime-producing Staphylococcus aureus strain, Vet. Res. 31 (2000) 603-609.

[2] Barta O., Neutrophil function tests. Chapter BIV. Phagocytosis and killing of bacteria monitored by sample cultivation, in Barta O. (Ed.), Veterinary clinical immunology laboratory, BarLab. Inc., Blacksburg, USA, 1993, pp. B3.12B3.17.

[3] Concha C., Cell types and their immunological functions in bovine mammary tissues and secretions - a review of the literature, Nord. Veterinaermed. 38 (1988) 257-272. 
[4] Daley M.J., Oldham E.R., Williams T.J., Coyle P.A., Quantitative and qualitative properties of host polymorphonuclear cells during experimentally induced Staphylococcus aureus mastitis in cows, Am. J. Vet. Res. 52 (1991) 471-479.

[5] Detilleux J.C., Kehrli M.E., Stabel J.R., Freeman A.E., Kelley D.H., Study of immunological dysfunction in periparturient Holstein cattle selected for high and average milk production, Vet. Immunol. Immunopathol. 44 (1995) 251-267.

[6] Dosogne H., Burvenich C., van Werven T., Roets E., Noordhuizen-Stassen E.N., Goodderis B., Increased surface expression of CD11b receptors on polymorphonuclear leukocytes is not sufficient to sustain phagocytosis during Escherichia coli mastitis in early postpartum dairy cows, Vet. Immunol. Immunopathol. 60 (1999) 47-59.

[7] Dosogne H., Vangroenweghe F., Barrio B., Rainard P., Burvenich C., Decreased number and bactericidal activity against $S$. aureus of the resident cells in milk of dairy cows during early lactation, J. Dairy Res. (to be published).

[8] Dulin A.M., Paape M.J., Nickerson S.C., Comparison of phagocytosis and chemiluminescence by blood and mammary gland neutrophils from multiparous and nulliparous cows, Am. J. Vet. Res. 49 (1988) 172-177.

[9] Hallén Sandgren C., Nordling K., Björk I., Isolation and phagocytic properties of neutrophils and other phagocytes from nonmastitic bovine milk, J. Dairy Sci. 74 (1991) 2965-2975.

[10] Hoeben D., Monfardini E., Opsomer G., Burvenich C., Dosogne H., De Kruif A., Beckers J.F., Chemiluminescence of bovine polymorphonuclear leucocytes during the periparturient period and relation with metabolic markers and bovine pregnancy-associated glycoprotein, J. Dairy Sci. 67 (2000) 249-259.

[11] Kehrli M.E., Nonnecke B.J., Roth J.A., Alterations in bovine peripheral blood neutrophil function during the periparturient period, Am. J. Vet. Res. 50 (1989) 207-214.

[12] Laevens H., Deluyker H., Schukken Y.H., De Meulemeester L., Vandermeersch R., De Meulenaere E., De Kruif A., Influence of parity and stage of lactation on the somatic cell count in bacteriologically negative dairy cows, J. Dairy Sci. 80 (1997) 3219-3226.

[13] Mehrzad J., Dosogne H., Meyer E., Burvenich C., Respiratory burst activity of bovine milk neutrophils during early and mid-lactation, Eur. J. Physiol. 438 (1999) R31.

[14] Moreira da Silva F., Burvenich C., Massart-Leën A.-M., Brossé L., Assessment of blood neutrophil oxidative burst activity in dairy cows during the early postpartum period, Animal Science 67 (1998) 421-426.

[15] Naidu T.G., Newbould F.H.S., Glycogen in leukocytes from bovine blood and milk, Can. J. Comp. Med. 37 (1973) 47-55.

[16] Paape M.J., Pearson R.E., Wergin W.P., Guidry A.J., Enhancement of chemotactic response of polymorphonuclear leukocytes into the mammary gland and isolation from milk, J. Dairy Sci. 60 (1976) 53-62.

[17] Paape M.J., Pearson R.E., Sources of variation in in vitro phagocytosis assays. Am. J. Vet. Res. 40 (1979) 630-635.

[18] Saad A.M., Flow cytometric measurement of bovine milk neutrophil phagocytosis, Acta Vet. Scand. 28 (1987) 333-342.

[19] Saad A., Hageltorn M., Flow cytometric characterisation of bovine blood neutrophil phagocytosis of fluorescent bacteria and zymosan particles, Acta Vet. Scand. 26 (1985) 289-307.

[20] Schepers A.J., Lam T.J.G.M., Schukken Y.H., Wilmink J.B.M., Hanekamp W.J.A., Estimation of variance components for somatic cell counts to determine thresholds for uninfected quarters, J. Dairy Sci. 80 (1997) 1833-1840.

[21] Shuster D.E., Lee E.K., Kehrli M.E., Bacterial growth, inflammatory cytokine production, and neutrophil recruitment during coliform mastitis in cows within ten days after calving, compared with cows at midlactation, Am. J. Vet. Res. 57 (1996) 1569-1575.

[22] Smits E., Burvenich C., Heyneman R., Simultaneous flow cytometric measurement of phagocytotic and oxidative burst activity of polymorphonuclear leukocytes in whole bovine blood, Vet. Immunol. Immunopathol. 56 (1997) 259269.

[23] Stevens M.G., Kehrli M.E., Canning P.C., A colorimetric assay for quantitating bovine neutrophil bactericidal activity, Vet. Immunol. Immunopathol. 28 (1991) 45-56.

[24] Vandeputte-Van Messom G., Burvenich C., Roets E., Massart-Leën A.-M., Heyneman R., Kremer W.D.J., Brand A., Classification of newly calved cows into moderate and severe responders to experimentally induced Escherichia coli mastitis, J. Dairy Res. 60 (1993) 19-29.

[25] Williams M.R., Craven N., Field T.R., Bunch K.J., The relationship between phagocytosis and intracellular killing of Staphylococcus aureus by bovine neutrophils, Br. Vet. J. 141 (1985) 362371. 